\title{
Effect of parathyroid hormone levels on the functional capacity and pulmonary function of patients on dialysis
}

\author{
Efeitos dos níveis de paratormônio sobre a capacidade \\ funcional física e pulmonar de pacientes dialíticos
}

Fabiana Santos Franco $\mathbb{D}^{\mathbb{D}}$, Joana D’arc Borges de Sousa $\mathbb{D}^{\mathbb{D}}$, Patrícia Leão da Silva Agostinho (D)*

Universidade Federal de Goiás (UFG), Jataí, GO, Brazil

\begin{abstract}
Introduction: Chronic kidney disease is characterized as the gradual loss of kidney function, with patients on dialysis experiencing a decline in functional capacity and pulmonary function. One of the non-traditional risk factors is parathyroid hormone (PTH), which influences metabolism and the status of the disease. Objective: Assess the effect of parathyroid hormone levels on functional capacity and pulmonary function in patients on dialysis. Method: Cross-sectional study with hemodynamically stable dialysis patients of both sexes, aged 18 to 59 years, who did not gain more than $2.5 \mathrm{~kg}$ between dialysis sessions. Two groups were created according to PTH blood levels: PTH (A), with values outside the normal range, and PTH (C), who exhibited normal levels of the hormone. Pulmonary function (PF) was assessed by spirometry and functional capacity (FC) via the six-minute walk test (6MWT). Results: The PTH A group displayed a negative association between PTH levels and PF, based on the values obtained for the spirometric variables forced expiratory volume in 1 second (FEV1) ( $\mathrm{r}=-0.54$ ) and forced vital capacity (FVC) ( $\mathrm{r}=-0.69)$. The average distance walked by the PTH (C) group was $343.85 \pm 98.14$ meters. Conclusion: The results suggest that high PTH levels have a negative effect on the PF of patients on dialysis.
\end{abstract}

*FSF: Master's Degree, e-mail: dra_fabianafranco@hotmail.com JDBS: Master's Degree, e-mail: joanabsfisio@fisio@outlook.com PLSA: PhD, e-mail: p.leao@hotmail.com 
Keywords: Chronic Renal Failure. Parathyroid Hormone. Spirometry. Walk Test.

\title{
Resumo
}

\begin{abstract}
Introdução: A Doença Renal Crônica (DRC) é caracterizada pela normalidade do funcionamento e da estrutura do rim. Nos pacientes dialíticos é observado um declínio da capacidade funcional pulmonar e física, que tem entre os fatores de risco não tradicionais, o paratormônio (PTH) que influencia no metabolismo e estado desta doença. Objetivo: Avaliar os efeitos dos níveis de paratormônio sobre a capacidade funcional física e pulmonar de pacientes dialíticos. Método: Foi realizado um estudo transversal com dialíticos de ambos os sexos, com idade entre 18 a 59 anos, hemodinamicamente estáveis, e que não apresentassem aumento de peso entre diálise $>2,5 \mathrm{~kg}$. Foram criados dois grupos de acordo com os níveis séricos de PTH: PTH (A) com valores fora da faixa de normalidade e PTH (C) com níveis normais de paratormônio. Foi realizada a avaliação da capacidade funcional pulmonar (CFP) pela espirometria e da capacidade funcional física (CFF) pelo teste de caminhada de seis minutos (TC6'). Resultados: Observou-se que o grupo PTH A apresentou associação negativa entre os níveis de PTH e a CFP referente aos valores as variáveis espirométricas, volume expirado forçado no primeiro minuto (VEF1) ( $r$ $=-0,54)$ e capacidade vital forçada (CVF) $(r=-0,69)$ no grupo PTH (A). A distância média percorrida pelo grupo PTH (C) foi de 343,85 \pm 98,14 metros. Conclusão: Os resultados sugerem que os níveis elevados de PTH exerce efeitos negativos sobre a CFP de pacientes dialíticos.
\end{abstract}

Palavras-chave: Insuficiência Renal Crônica. Hormônio Paratireóideo. Espirometria. Teste de caminhada.

\section{Introduction}

Chronic kidney disease (CKD) causes damage to the renal parenchyma, with progressive and irreversible loss of kidney function, resulting in their inability to control metabolic, fluid and electrolyte balance [1].

The disease is characterized by a glomerular filtration rate (GFR) $<60 \mathrm{~mL} / \mathrm{min} / 1.73 \mathrm{~m}^{2}$ over a period greater than or equal to 3 months, with GFR $<15 \mathrm{~mL} /$ $\mathrm{min} / 1.73 \mathrm{~m}^{2}$ classified as end-stage or stage 5 CKD $[1,2]$. In addition to controlling levels of phosphorus, vitamin D and PTH, recommended treatment at this stage to artificially filter the blood includes a kidney transplant, peritoneal dialysis or hemodialysis (HD), the last being the most widely used [2]. In accordance with the 2016 Brazilian chronic dialysis survey, $92 \%$ of patients with CKD were undergoing HD [3].

Renal failure leads to changes in mineral metabolism, compromising blood levels of calcium (Ca), phosphorus $(\mathrm{P})$ and the regulatory hormones parathyroid hormone (PTH), 1,25 - dihydroxyvitamin D (calcitriol) and fibroblast growth factor 23 (FGF23), which can cause CKD-mineral and bone disorder (CKD-MBD) [3].

Abnormal PTH levels and HD are associated with musculoskeletal system and functional impairment, thereby increasing the morbidity and mortality of these patients [4-7]. High levels of this hormone influence synthesis and the use of muscular energy, interfering in amino acid and protein metabolism in the musculoskeletal system $[5,6]$.

The respiratory system is also affected by CKD and HD, since both uremia and PTH, considered the main uremic toxin, compromise lung function $[1,8]$. Thus, patients on HD may also exhibit respiratory disorders, limited distal airflow and reduced diffusing capacity of the lungs due to vitamin D deficiency [9] and high PTH levels [8].

It is important to note that loss of kidney function leads to phosphate retention, which is offset by increased FGF23 and PTH excretion. Analysis of PTH levels indicated that values above $500 \mathrm{pg} / \mathrm{ml}$ can generate physiological changes that result in a clinical picture characterized by musculoskeletal disorders, since the hormone affects synthesis and the use of energy, interfering in amino acid and protein metabolism in musculoskeletal structures [6].

As such, patients with CKD may experience a decrease in functional capacity (FC) and pulmonary function (PF) [10]. In patients on dialysis, FC is around 50\% lower than that of healthy individuals [11].

However, research on the influence of PTH level on FC and PF in dialysis patients is scarce. In light of the 
above, the aim of this study was to assess the effect of high PTH levels on the FC of patients on dialysis.

\section{Method}

This is a cross-sectional study with a descriptive approach. It was approved by the Research Ethics Committee of the Federal University of Goiás, under protocol number 2.219.649, and conducted in line with the ethical principles of Ministry of Health Resolutions 466/12 and 510/16.

The sample consisted of patients of both sexes, diagnosed with end-stage CKD and on dialysis for at least three months, three hours a day and twice a week, registered at the Hemodialysis Clinic in the city of Jataí, Goiás state (GO), Brazil, where the study was conducted.

Participants were aged between 18 and 59 years, mentally and physically equipped to cope with the methodological instruments applied, hemodynamically stable (systolic $<200 \mathrm{mmHg}$ and/or diastolic pressure $>50 \mathrm{mmHg}$ ), authorized by their doctor to perform the physical test (six-minute walk test - 6MWT), non-smokers, and who did not exhibit liver or chronic obstructive pulmonary disease, heart failure, active infection or gain $>2.5 \mathrm{~kg}$ between dialysis sessions. They were required to provide comprehensive medical charts containing all the data needed for the study, and specific biochemical analyses for PTH.

Those who did not provide these analyses, were unable to perform the physical and pulmonary function tests, exhibited lower limb deformities or had difficulty coping with the instruments applied were excluded. Additionally, patients who were hemodynamically unstable, taking medication or substances that might alter bone metabolism (aluminum, GnRH analogs, anticonvulsants, cadmium, cyclosporine A, cholestyramine, corticosteroids, thyroid hormone, methotrexate, opiates or derivatives, and oral retinoids), smokers, heavy drinkers, had been diagnosed with liver or chronic obstructive pulmonary disease, heart failure, active infection, or gained $>2.5 \mathrm{~kg}$ between dialysis sessions were also excluded from the study.

Data collection was performed by two trained physiotherapists and monitored by the physicians responsible for the clinic. A pilot study was carried out to adjust data collection, which proceeded as follows: giving written informed consent, anamnesis, anthropometric assessment, pulmonary function testing (PFT) and 6MWT. The 6MWT was conducted in the clinic's indoor parking lot and the remaining assessments in a room at the hemodialysis clinic.

The biochemical tests were performed in line with the relevant recommendations $[1,12]$, in partnership with the clinic. Phosphorus, vitamin D and calcium levels were measured in blood samples obtained at predialysis. Serum intact PTH was measured by chemiluminescence, with an IMMULITE ${ }^{\circledR} 2000$ Intact PTH kit [6].

Volunteers were divided into two groups, based on the recommended PTH levels for dialysis patients: PTH (A), for values outside the normal range ( $\geq$ que $500 \mathrm{pg}$ / $\mathrm{ml}$ ), and PTH (C), for those with normal levels of the hormone (101- $499 \mathrm{pg} / \mathrm{ml}$ ) [3].

Weight $(\mathrm{kg})$ and height $(\mathrm{cm})$ were determined on an electronic balance with integrated stadiometer (Filizola ${ }^{\circledR}$ PL-200, Recife, Brazil). Body mass index (BMI) was calculated from the dry weight in kilograms, using the formula weight $/$ height $^{2}$ [13].

The PFT tests were conducted in accordance with the Brazilian Guidelines for Pulmonary Function Testing [14], by a trained physical therapist, using a Clement Clarke One Flow ${ }^{\circledR}$ spirometer (ISSO 13485 and 93/42/ EEC, England). The parameters assessed were forced expiratory volume in 1 second (FEV1); forced vital capacity (FVC); FEV1/FVC ratio (FEV1/FVC), peak expiratory flow (PEF) and forced expiratory flow at $25-75 \%$ of vital capacity (FEF25-75\%). The prediction equations of the European Respiratory Society (ERS) were used, with values presented in the tables as percentages according to sex and height $[15,16]$.

Functional capacity was evaluated by the 6MWT, in line with American Thoracic Society recommendations [17]. The parameters assessed were distance walked, respiratory rate (RR), blood pressure (BP), heart rate (HR), oxygen saturation (Sp02) and degree of dyspnea and fatigue by the Modified Borg Scale. The vital signs were measured before the test and in the first and second minute after its completion $[18,19]$. The predicted distance walked (\%) in the 6MWT was calculated using the equation for the Brazilian population developed by Britto [20].

Data were analyzed using SPSS software version 20.0 for Windows and expressed as mean $( \pm$ ) standard deviation. The Shapiro-Wilk test was applied to assess data normality and the Mann-Whitney test for comparisons, depending on data distribution. Spearman's test was used for correlation analyses. Statistical significance was set at $\mathrm{p}<0.05$. 


\section{Results}

Of the 139 patients treated at the Jataí Hemodialysis Center, 23 were eligible, 13 with normal PTH levels (PTH (C) group) and 10 with above-normal values (PTH (A) group) (Figure 1). The general characteristics of the patients in accordance with their PTH levels are presented in Table 1.

Tables 2 and 3 show the results of FC and PF assessments for both groups, with no statistical difference between them for the functional variables analyzed (Table
2). With regard to $\mathrm{FC}$, the average distance walked and predicted percentage obtained were $343.85 \pm 98.14$ meters and $42.35 \%$ for the PTH (C) group and $385.60 \pm 94.14$ meters and $47.04 \%$ for the PTH (A), respectively (Table 3 ).

In the PTH (A) group, a negative correlation was observed between PTH levels and PF, represented by the spirometric variable FVC $(r=-0.69)$ in the PTH group (A) (Figure 2). PTH levels were not correlated with FC in either group.

Table 1 - General characteristics of patients according to PTH levels

\begin{tabular}{lcccc}
\hline \multicolumn{1}{c}{ Variable } & Reference Value & $\begin{array}{c}\text { PTH (C) } \\
\mathbf{N = 1 3}\end{array}$ & $\begin{array}{c}\text { PTH (A) } \\
\mathbf{N = 1 0}\end{array}$ & $\boldsymbol{P}$ \\
\hline Age, years & & $43.62 \pm 12.57$ & $37.80 \pm 14.42$ & 0.56 \\
Females & 3 & 4 & 0.65 \\
Height (cm) & & $167.54 \pm 11.47$ & $160.70 \pm 13.91$ & 0.25 \\
Weight (kg) & & $73.31 \pm 15.54$ & $57.60 \pm 10.00$ & 0.05 \\
Dry weight (kg) & & $71.23 \pm 15.56$ & $56.60 \pm 10.28$ & 0.05 \\
IMC (Kg/m²) & & $25.49 \pm 5.55$ & $21.89 \pm 2.51$ & 0.05 \\
Hemodialysis time & & $33.08 \pm 25.56$ & $52.38 \pm 18.22$ & 0.32 \\
(months) & & $325.84 \pm 96.20$ & $1186.80 \pm 632.38$ & 0.03 \\
PTH (pg/ml) & 101 a 499 & $1.14 \pm 0.11$ & $1.18 \pm 0.09$ & 0.71 \\
Calcium (millimol/L) & 1.12 a 1.32 & $6.26 \pm 1.70$ & $7.92 \pm 2.26$ & 0.06 \\
Phosphorus (mg/dL) & 2.5 a 4.8 & $41.70 \pm 12.01$ & $53.73 \pm 21.92$ & 0.19 \\
Vitamin D (ng/mL) & 30 a 60 & &
\end{tabular}

Note: $\mathrm{PTH}=$ parathyroid hormone; $\mathrm{kg}=$ kilogram, $\mathrm{pg} / \mathrm{ml}=$ picogram/milliliter; $\mathrm{mg}=$ microgram/deciliter $(\mathrm{p}>0.05)$ Reference value [20] MannWhitney test.

139 patients

Diagnosed wish CKD and registered at the Hemodialysis Clinic

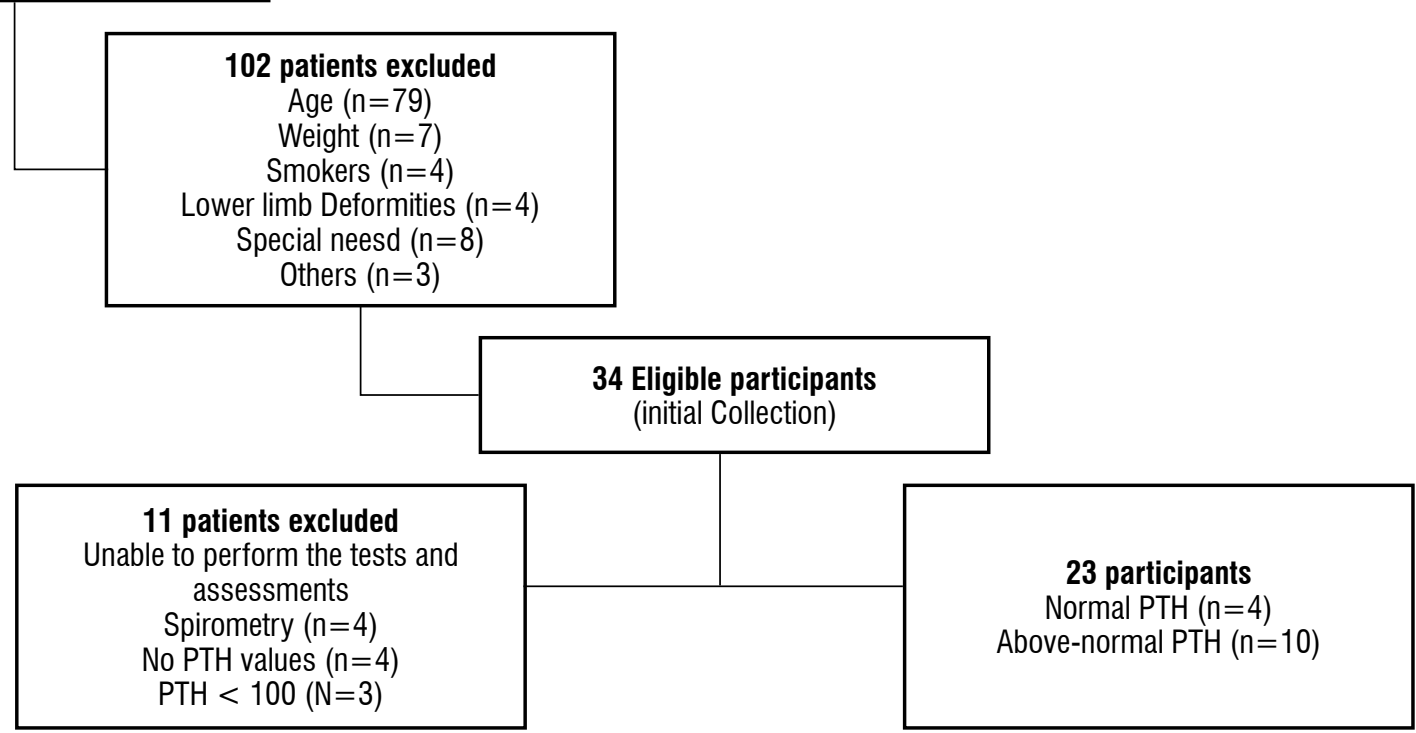

Figure 1 - Flowchart of the population. 
Table 2 - Pulmonary function data for both groups

\begin{tabular}{|c|c|c|c|}
\hline Variables & $\begin{array}{c}\text { PTH (C) } \\
\mathrm{N}=13\end{array}$ & $\begin{array}{c}\text { PTH (A) } \\
\mathrm{N}=10\end{array}$ & p-value \\
\hline $\mathrm{PEF}_{\text {(predicted \%) }}$ & $86.08 \pm 27.56$ & $76.50 \pm 20.00$ & 0.37 \\
\hline FEV1 (predicted \%) & $76.00 \pm 17.19$ & $66.50 \pm 16.22$ & 0.23 \\
\hline FVC\% ${ }_{\text {(predicted \%) }}$ & $73.38 \pm 17.48$ & $73.10 \pm 22.48$ & 0.98 \\
\hline FEV1/FVC ${ }_{\text {(predicted \%) }}$ & $87.62 \pm 12.90$ & $80.60 \pm 18.85$ & 0.41 \\
\hline $\mathrm{FEF}_{(25 / 75 \%)(\text { predicted \%) }}$ & $76.69 \pm 48.29$ & $68.22 \pm 34.86$ & 0.60 \\
\hline
\end{tabular}

Note: PEF=peak expiratory flow; FEV1=forced expiratory flow in 1 second; FVC=forced vital capacity; FEV1/FVC=ratio between forced expiratory flow in 1 second and vital capacity; FEF=forced expiratory flow at $25-75 \%$ of vital capacity. Mann-Whitney.

Table 3 - Functional capacity data of the 6MWT for both groups

\begin{tabular}{|c|c|c|c|}
\hline Variables & $\begin{array}{c}\text { PTH (C) } \\
\mathrm{N}=13\end{array}$ & $\begin{array}{c}\text { PTH (A) } \\
\mathrm{N}=10\end{array}$ & $\begin{array}{c}\mathbf{p} \text {-value } \\
\mathbf{p}\end{array}$ \\
\hline Systolic BP $_{(0)(\mathrm{mmHg})}$ & $154.46 \pm 28.42$ & $159.20 \pm 22.89$ & 0.73 \\
\hline Systolic BP $_{(1)(\mathrm{mmHg})}$ & $158.85 \pm 28.96$ & $157.60 \pm 20.54$ & 0.87 \\
\hline Systolic BP $_{\text {(2) (mmHg) }}$ & $149.85 \pm 26.08$ & $153.10 \pm 22.65$ & 0.73 \\
\hline 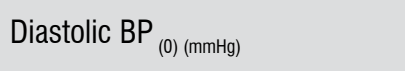 & $96.85 \pm 24.02$ & $107.10 \pm 21.41$ & 0.23 \\
\hline Diastolic $_{\text {BP (1) (mmHg) }}$ & $102.54 \pm 30.12$ & $104.00 \pm 21.19$ & 0.48 \\
\hline Diastolic $_{\text {BP (2) (mmHg) }}$ & $98.08 \pm 26.99$ & $95.50 \pm 12.00$ & 0.78 \\
\hline $\mathrm{SpO}_{2(0)}$ & $98.08 \pm 0.95$ & $96.90 \pm 2.51$ & 0.28 \\
\hline $\mathrm{SpO}_{2(1)}$ & $97.62 \pm 1.12$ & $97.10 \pm 3.31$ & 0.60 \\
\hline $\mathrm{SpO}_{2(2)}$ & $97.92 \pm 0.95$ & $96.50 \pm 5.14$ & 0.98 \\
\hline $\mathrm{RR}(0)_{(\mathrm{rmm})}$ & $17.85 \pm 4.50$ & $17.60 \pm 4.69$ & 0.83 \\
\hline $\mathrm{RR}(1)_{(\mathrm{rpm})}$ & $20.00 \pm 5.16$ & $19.20 \pm 6.19$ & 0.60 \\
\hline $\mathrm{RR}(2)_{(\mathrm{rpm})}$ & $17.54 \pm 4.17$ & $16.90 \pm 4.33$ & 0.69 \\
\hline $\mathrm{HR}(0)_{(\mathrm{bpm})}$ & $84.54 \pm 11.88$ & $74.70 \pm 14.87$ & 0.10 \\
\hline $\mathrm{HC}(1)_{(\mathrm{bpm})}$ & $88.46 \pm 13.08$ & $78.80 \pm 16.48$ & 0.16 \\
\hline $\mathrm{HC}(2)_{(\mathrm{bpm})}$ & $87.31 \pm 12.32$ & $78.40 \pm 16.64$ & 0.18 \\
\hline $\mathrm{BORG}_{(0)}$ & $1.69 \pm 2.09$ & $0.70 \pm 0.94$ & 0.41 \\
\hline $\mathrm{BORG}_{(1)}$ & $3.62 \pm 2.72$ & $3.10 \pm 2.13$ & 0.73 \\
\hline $\mathrm{BORG}_{(2)}$ & $1.33 \pm 1.23$ & $1.60 \pm 1.64$ & 0.82 \\
\hline Distance walked $_{(\mathrm{m})}$ & $343.85 \pm 98.14$ & $385.60 \pm 94.14$ & 0.52 \\
\hline Distance walked $_{\text {(predicted \%) }}$ & $42.35 \pm 11.27$ & $47.04 \pm 9.06$ & 0.68 \\
\hline
\end{tabular}

Note: $6 \mathrm{MWT}=$ Six-minute walk test; $\mathrm{PTH}=$ parathyroid hormone; $\mathrm{BP}=\mathrm{Blood}$ pressure; $\mathrm{SpO}_{2}=$ oxygen saturation; $\mathrm{RR}=$ respiratory rate; $H R=$ Heart rate. (0) pre-walk test; (1) first minute after the walk test; (2) second minute after the walk test. Mann-Whitney test. 


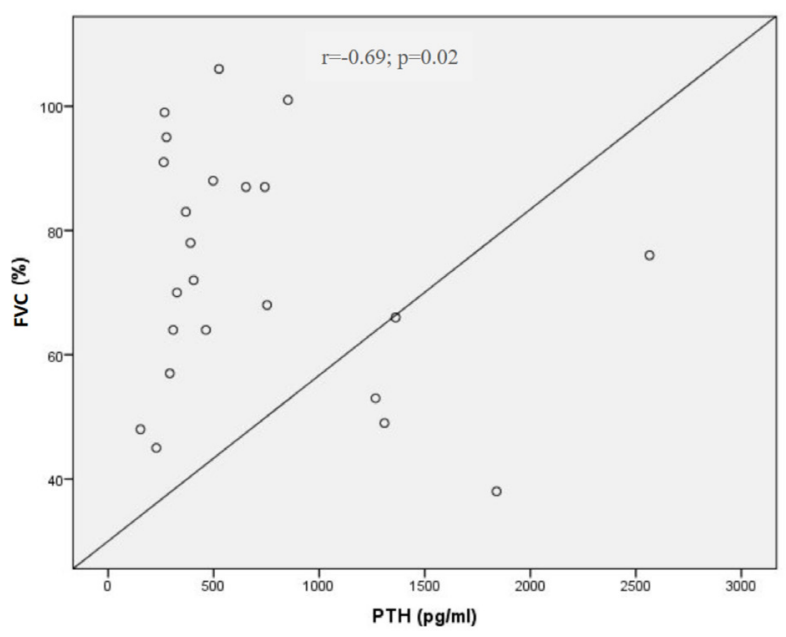

Figure 2 - Correlation between FVC (\%) and PTH levels in group (A). Spearman's correlation coefficient.

\section{Discussion}

This study demonstrated that PTH levels were negatively associated with PF in dialysis patients with abovenormal PTH concentrations.

Changes in PTH levels, inflammation, anemia, oxidative stress and mineral metabolism disorders are non-traditional risk factors associated with increased morbidity and mortality in patients on dialysis [4].

It is important to note that loss of kidney function leads to phosphate retention, which is offset by increased FGF23 and PTH excretion [6]. As a result, as GFR decreases, this compensatory mechanism becomes insufficient to maintain normal phosphorus levels, leading to hyperphosphatemia, which induces hypocalcemia [18]. The supplements Calcitriol ${ }^{\circledR}$ and Renagel ${ }^{\circledR}$ were used by volunteers in the present study to control these levels.

Parathyroid hormone is the main uremic toxin [1], with high levels leading to increased bone loss, aortic valve and vascular calcification, polyneuropathy, glucose intolerance, dyslipidemia and inflammation $[5,18]$, in addition to being associated with heart disease and immunosuppression [21,22].

In this context, previous studies have shown that changes in the uremic status of patients on dialysis influence $\mathrm{FC}$, which is defined as the ability to perform tasks and activities that people find necessary or desirable in their lives, with negative effects including muscle weakness and respiratory disorders [9,23].
There are no studies in the literature that analyze the influence of PTH levels or other uremic toxins on PF in dialysis patients. This makes the findings of the present study noteworthy, since a correlation was observed between PTH and PF in patients with above-normal PTH levels, adjusted for confounding factors such as age, dry weight and assessment moment.

In this respect, PTH levels had a negative effect on musculoskeletal function [6]. In our study, the distance walked in both groups was shorter than that predicted and below the lower limit of normal for Brazilians in the 6MWT [20], which can be justified by the fact that, regardless of their serum PTH levels, both groups were undergoing hemodialysis.

In line with our findings, previous studies $[24,25]$ also reported shorter distances traveled by patients on dialysis, suggesting that dialysis itself is a contributing factor to the decline in functional capacity among these individuals.

As CKD progresses, patients with high PTH levels and vitamin $D$ deficiency experience a decline in muscle strength [26]. In patients on dialysis, this can lead to physical disability and greater difficulty performing activities of daily living $[21,27]$. This progressive pathophysiological process is attributed to uremia, which leads to a decrease in the proportion of contractile tissue in the sarcomere and, consequently, contractile inefficiency $[4,8,28]$. In the present study, the PF parameters of dialysis patients declined by more than $10 \%$ when compared to predicted values reported in the literature (Table 2), corroborating prior research [19,29].

Kidney disease is not a localized condition and leads to progressive irreversible loss of kidney function, affecting both the kidney and the systems of related organs [30]. Metabolic disorders result in reduced ventilatory responses, since CKD causes a gradual decline in respiratory muscle strength, which is exacerbated by the length of hemodialysis treatment [31] and the individual's fluid retention $[4,32]$. However, these confounding factors were controlled because the patients studied gained less than $2.5 \mathrm{~kg}$ between hemodialysis sessions and the same assessment moments were applied for all participants.

Metabolic changes in patients on hemodialysis compromise lung function [33-35], since CKD selectively affects large nerve fibers such as the phrenic nerve, which innervates the diaphragm [23]. Uremic toxin retention not only overloads the respiratory muscles, but affects chest muscle mechanics, resulting in musculoskeletal 
disorders, loss of capillary action and a decline in contractile proteins and muscle mass [7,35].

The limitations of our study are the sample size and lack of a control group without CKD. However, all the eligible individuals from the Hemodialysis Center were assessed and groups were matched for anthropometric variables, sex and age.

Additionally, our findings demonstrate an important consequence of increased PTH levels, not yet reported in the literature.

Thus, the present study found that high PTH levels negatively affected pulmonary function but did not interfere in functional capacity. Nevertheless, patients on dialysis exhibited important impairments in functional capacity.

\section{Acknowledgements}

The authors are grateful to the patients, doctors, nurses and other personnel at the Jataí Hemodialysis Clinic who collaborated with this study.

\section{References}

1. Andrassy KM. Comments on 'KDIGO 2012 clinical practice guideline for the evaluation and management of chronic kidney disease'. Kidney International. 2013 [cited 2019 Jul 7]. Available from: http://linkinghub. elsevier.com/retrieve/pii/S0085253815560067

2. Rocha ERE, Magalhães SM, Lima VP. Repercussion of physiotherapy intradialytic protocol for respiratory muscle function, grip strength and quality of life of patients with chronic renal diseases. J Bras Nefrol. 2010;32(4):355-66.

3. Sesso RC, Lopes AA, Thomé FS, Lugon JR, Martins CT. Brazilian Chronic Dialysis Survey 2016. J Bras Nefrol. 2017;39(3):261-6.

4. Kazama JJ. Chronic kidney disease and fragility fracture. Clin Exp Nephrol. 2017;21(Suppl 1):46-52.

5. Albuquerque RFC, Carbonara CEM, Martin RCT, Reis LM, Nascimento Jr CP, Arap SS, et al. Parathyroidectomy in patients with chronic kidney disease: Impacts of different techniques on the biochemical and clinical evolution of secondary hyperparathyroidism. Surgery. 2018;163(2):381-7.
6. Campos SR, Gusmão MHL, Fortes A, Sampaio LR, Barreto JM. Estado nutricional e ingestão Estado nutricional e ingestão alimentar de pacientes em diálise peritoneal contínua com e sem hiperparatireoidismo secundário.J Bras Nefrol. 2012;34(2):170-7.

7. Verdelli C, Corbetta S. Epigenetic alterations in parathyroid cancers. Int J Mol Sci. 2017;18(2):1-13.

8. Coelho DM, Castro ADM, Tavares HA, Abreu PBC, Glória RR, Duarte MH, et al. Efeitos de um Programa de Exercícios Físicos no Condicionamento de Pacientes em Hemodiálise. J Bras Nefrol. 2006;28(3):121-7.

9. Duarte J, Medeiros RF, Di Pietro T, Lopes TM. Alterações de volumes e capacidades pulmonares pré e pós-hemodiálise em insuficiência renal crônica TT Changes in lung volume and capacity before and after hemodialysis in chronic renal failure. J Heal Sci Inst. 2011;29(1):70-2.

10. Nascimento LCA, Coutinho ÉB, Silva KNG. Efetividade do exercício físico na insuficiência renal crônica. Fisioter Mov. 2012;25(1):231-9.

11. Fassbinder TRC, Winkelmann ER, Schneider J, Wendland J, Oliveira OB. Functional Capacity and Quality of Life in Patients with Chronic Kidney Disease In Pre-Dialytic Treatment and on Hemodialysis - A Cross sectional study. J Bras Nefrol. 2015;37(1):47-54.

12. Giachini E, Zanesco C, Souza SS, Ceratto PC, Resende e Silva DT. Perfil de Pacientes hemodialíticos relacionados a parâmetros bioquímicos e hematológicos no oeste catarinense. Colloq Vitae. 2017;9(2):37-44.

13. Mancini MC (Ed.). Diretrizes brasileiras de obesidade. 4th ed. São Paulo: ABESO; 2016.

14. SBPT. Diretrizes da Sociedade Brasileira de Pneumologia e Tisiologia para o Manejo da Asma - 2012. J Bras Pneumol. 2012;38(Suppl. 1):S1-46.

15. Quanjer PH, Stanojevic S, Cole TJ, Baur X, Hall GL, Culver $\mathrm{BH}$, et al. Multiethnic reference values for spirometry for the 3-95-yr age range: The global lung function 2012 equations. Eur Respir J. 2012;40(6):1324-43.

16. Pereira CAC. Espirometria.J Bras Pneumol. 2002;28(Suppl. 3):S1-82.

17. ATS. Guidelines for the six-minute walk test. Am J Respir Crit Care Med. 2002;166(1):111-7.

18. Watanabe F, Koch V, Juliani R, Cunha M. Six-minute walk test in children andadolescents with renal diseases: tolerance, reproducibility and comparison with healthy subjects. Clinics. 2016;71(1):22-7. 
19. Jaqueto M, Delfino VDA, Bortolasci CC, Barbosa DS, Morimoto HK, Frange RFN, et al. Are PTH levels related to oxidative stress and inflammation in chronic kidney disease patients on hemodialysis? J Bras Nefrol. 2016;38(3):288-95.

20. Britto RR, Probst VS. Reference equations for the sixminute walk distance based on a Brazilian multicenter study. Braz J Phys Ther. 2013;17(6):556-63.

21. Hornik B, Duława J, Szewieczek J, Durmała J. Physical activity increases the resistin concentration in hemodialyzed patients without metabolic syndrome. Dove Press J. 2019;12:43-57.

22. Palamidas AF, Gennimata SA, Karakontaki F, Kaltsakas G, Papantoniou I, Koutsoukou A, et al. Impact of hemodialysis on dyspnea and lung function in end stage kidney disease patients. Biomed Res Int. 2014;2014:212751.

23. Olaizola I, Caorsi H, Fajardo L, Ferreiro A, Campistrus N, Dolinsky D, et al. Effectiveness and safety of a 6-month treatment with paricalcitol in patients on hemodialysis with secondary hyperparathyroidism. J Bras Nefrol. 2016;38(3):302-12.

24. Jatobá JPC, Amaro WF, Andrade APA, Cardoso FPF, Monteiro AMH, Oliveira MAM. Avaliação da função pulmonar, força muscular respiratória e teste de caminhada de seis minutos em pacientes portadores de doença renal crônica em hemodiálise. J Bras Nefrol. 2008;30(4):280-7.

25. Reboredo MDM, Michela D, Henrique N. Exercício físico em pacientes dialisados. Rev Bras Med Esporte. 2007;13(6):427-30.

26. Jean G, Souberbielle JC, Chazot C. Vitamin D in chronic kidney disease and dialysis patients. Nutrients. 2017;9(4):1-15.

27. Loth DW, Lahousse L, Leening MJG, Krijthe BP, Felix JF, Gall H, et al. Pulmonary function and diffusion capacity are associated with pulmonary arterial systolic pressure in the general population: The Rotterdam Study. Respir Med. 2017;132:50-5.
28. Ribeiro R, Coutinho GL, Iuras A, Barbosa AM, Souza JAC, Diniz DP, et al. Effect of resistance exercise intradialytic in renal patients chronic in hemodialysis. J Bras Nefrol. 2013;35(1):13-9.

29. Ramírez BV, Gómez PAB. Uraemic neuropathy: A review. Int J Genet Mol Biol. 2012;3(11):155-60.

30. Ding Y, Wang H, Zou Q Jin Y, Zhang Z, Huang J. Factors associated with calcium requirements after parathyroidectomy in chronic kidney disease patients. Int Urol Nephrol. 2018;50(3):535-40.

31. Yllmaz S, Yildirim Y, Yilmaz Z, Kara AV, Taylan M, Demir $\mathrm{M}$, et al. Pulmonary function in patients with end-stage renal disease: effects of hemodialysis and fluid overload. Med Sci Monit. 2016;22:2779-84.

32. Gomes TS, Aoike DT, Baria F, Graciolli FG, Moyses RMA, Cuppari L. Effect of aerobic exercise on markers of bone metabolism of overweight and obese patients with chronic kidney disease. J Ren Nutr. 2017;27(5):364-71.

33. Menezes Jr CAV, Guia MJ, Perão KA, Santos E. Repercussões da doença renal crônica e da hemodiálise na função pulmonar: uma revisão bibliográfica. UNILUS Ensino Pesqui. 2013;10(20):21-34.

34. Silva VG, Amaral C, Monteiro MB, Nascimento DM, Boschetti JR. Efeitos do treinamento muscular inspiratório nos pacientes em hemodiálise Effects of inspiratory muscle training in hemodialysis patients. J Bras Nefrol. 2010;33(1):62-8.

35. Gomes LK, Custódio MR, Contieri FLC, Riella MC, Nascimento MM. Persistent disorders of mineral metabolism after one year of kidney transplantation. J Bras Nefrol. 2016;38(3):282-7.
Received: 08/14/2019

Recebido: 14/08/2019

Approved: 06/26/2020

Aprovado: 26/06/2020 